\title{
Effect of stage of maturity, cultivar, nitrate fertilization, soil type on mineral content of sugarcane ${ }^{1}$
}

\author{
Gilles Aumont ${ }^{2}$ and Michel Salas ${ }^{3}$
}

J. Agric. Univ. P.R. 80(1-2):37-46 (1996)

\begin{abstract}
The effect of the stage of maturity, cultivar, nitrate fertilization and soil type on the mineral content of sugarcane (Saccharum officinarum L.) was determined in Guadeloupe in two experiments. The calcium, phosphorus, sulfur, magnesium, sodium, potassium, zinc, copper, manganese and molibdenum contents of tops, stalks and whole plants were determined in sugarcane of 14 cultivars at two stages of maturity ( $8 \mathrm{vs} .12 \mathrm{mo}$ ) in an experiment in an acid soil area. The procedures were repeated in a second experiment in a calcareous soil area with two cultivars (B 69379 vs. B 744708 ) and three nitrate fertilization levels $(80,150,300 \mathrm{~kg} \mathrm{~N} / \mathrm{ha} / \mathrm{yr})$. The mean $\mathrm{Ca}, \mathrm{P}, \mathrm{S}, \mathrm{Mg}$, $\mathrm{Na}, \mathrm{K}$ contents of whole plants were $1.27,1.86,1.88,0.89,0.20,5.87 \mathrm{~g} / \mathrm{kg} \mathrm{dry}$ matter (DM), respectively, in experiment 1 . The mean $\mathrm{Zn}, \mathrm{Cu}, \mathrm{Mn}$, Mo contents of whole plants were $17.2,1.8,89.2$ and $0.4 \mathrm{mg} / \mathrm{kg} \mathrm{DM}$, respectively, in experiment 1 . The mineral contents of tops were generally higher than those of stalks. Nitrate fertilization and stage of maturity had little effect on the mineral content of sugarcane.
\end{abstract}

Key words: mineral content, sugarcane, nitrate fertilization, Saccharum officinarum

\section{RESUMEN}

Etapa de crecimiento, cultivar, fertilización nitrogenada, tipo de suelo y el contenido de minerales en la caña de azúcar

En dos experimentos realizados en Guadalupe, se estudió el efecto de la etapa de crecimiento, de la cultivar, de la fertilización nitrogenada y del típo de suelo sobre el contenido de minerales de la caña de azúcar (Saccharum officinarum L.). En el primer experimento, establecido en un suelo ácido, se midió el contenido de calcio, fósforo, azufre, magnesio, sodio, potasio, zinc, cobre, manganeso y molibdeno en los cogollos, cañas y plantas enteras de 14 variedades y en dos etapas de crecimiento diferentes ( 8 y 12 meses). El mismo procedimiento se repitió en un segundo experimento donde, en un suelo calcáreo, se sembraron dos cultivares de caña (B 69379 y B 744708) y se aplicaron tres dosis de nitrógeno $(80,150$ y $300 \mathrm{~kg} / \mathrm{ha} / \mathrm{año})$. El contenido medio de $\mathrm{Ca}, \mathrm{P}, \mathrm{S}, \mathrm{Mg}$, $\mathrm{Na}$ y $\mathrm{K}$ en plantas enteras fue $1.27,1.86,1.88,0.89$, $0.20,5.87 \mathrm{~g} / \mathrm{kg}$ de materia seca (ms), respectivamente, en el primer experimento. El contenido medio de $\mathrm{Zn}, \mathrm{Cu}, \mathrm{Mn}$ y Mo en plantas enteras fue 17.2,

Manuscript submitted to Editorial Board 30 April 1993.

${ }^{2}$ Institut National de la Recherche Agronomique, Unité de Recherches Zootechniques, BP 515, 97165 Pointe à Pitre Cédex, Guadeloupe (French West Indies).

${ }^{3}$ Institut d'Elevage et de Médecine Vétévinaire des Pays Tropicaux, BP 515, 97165 Pointe à Pitre Cédex, Guadeloupe (French West Indies). 
$1.8,89.2$ y $0.4 \mathrm{mg} / \mathrm{kg} \mathrm{ms}$, respectivamente, en el primer experimento. Los contenidos de minerales de los cogollos fueron superiores a los de las cañas. La fertilización nitrogenada y la etapa de crecimiento tuvieron poco efecto sobre el contenido de minerales de la caña de azúcar.

\section{INTRODUCTION}

Sugarcane has desirable nutritional characteristics for cattle production (Preston, 1977). It has a high dry matter (DM) yield and is well adapted to areas with an extended dry season. Information on its mineral content is limited, and mineral imbalances may reduce production when diets contain high levels of sugarcane without supplementation. The objectives of this study were to examine the factors which affect the nutritive values and mineral content of sugarcane grown in Guadeloupe (F.W.I.), in terms of ruminant feeding purposes. Results of nutritive values of sugarcanes from these experiments were detailed by Salas et al. (1992). Macro-minerals and trace element concentrations were determined in a limited number of samples according to an equilibrated design plan, and are presented in this paper. Soil characteristics, particularly soil $\mathrm{pH}$, are known to affect the mineral content of plants (Minson, 1990; Underwood, 1981). In this study, experiments were conducted on Oxisols and Vertisols, which are very common in the Caribbean where sugarcane is a major agricultural product. In a first experiment, the effects of the stage of maturity of 14 cultivars on mineral content were determined in sugarcane grown in acid soils. In a second experiment, we estimated the effects of nitrate fertilization on the nutritive values of two cultivars frequently cultivated in the swelling clay soils (Vertisols) of Guadeloupe. Ruminant feeding practices with diet based on sugarcane largely depend on the part of plants, either stalks or tops. Thus in each experiment, stalks and tops were analyzed separately.

\section{MATERLALS AND METHODS}

\section{Experiment 1}

This experiment was carried out in 1988. Fourteen different cultivars of sugarcane were used (MY 5465, H 328560, BJ 7058, B 69566, CB 80008, UBA MAR., CP 61037, Q 110, B 69379, FR 80260, FR 80842, B 47258, Pt Schermol and Gd Schermol). These cultivars are widely used in Guadeloupe and Martinique (F.W.I.) for sugar and alcohol production. The sugar/fiber ratio of these cultivars ranged from 0.79 to 1.05 (Salas et al., 1992). The plants were grown at a research station located on an Oxisol cover developed on lightly weathered andesitic volcanic deposits. In the West Indies, the $\mathrm{pH}$ of these types of soils 
ranges between 4.5 and 6.0 . The phosphorus availability as defined by Ayres and Hagihara (1961) ranged between 35 and $52 \mathrm{mg} P / \mathrm{kg}$ in Truog-Ayres buffer extract. The cation exchange capacity (CEC) ranged from 30 to $20 \mathrm{mmol} / \mathrm{kg}$ (Colmet-Daage, 1982). Fertilization levels were $80 \mathrm{~kg}$ of N/ha/yr, $40 \mathrm{~kg}$ of $\mathrm{P} / \mathrm{ha} / \mathrm{yr}, 170 \mathrm{~kg}$ of $\mathrm{k} / \mathrm{ha} / \mathrm{yr}$, in a single application, 1.5 month after the beginning of the experiment. Sugarcane was harvested eight and 12 mo after planting. Husbandry operations were carried out according to sugar industry recommendations (C.T.I.C.S., 1987): weedings, treatments against parasitosis, irrigation one day per week during the first three months. For each of the 52 examples (three repetitions per cultivar), three whole plants were obtained from the middle rows of plots (one plot per sample). Tops were defined as the upper part of the plant from the last ring plus the dry leaves. Dry matter of stalks and tops was analyzed separately. Mineral content of the whole plant was calculated after adjusting the concentrations by the ratio of the weight of tops to the weight of tops and stalks.

\section{Experiment 2}

Experiment 2 was carried out in 1989. It was located on calcomagnesian Vertisols overlying coral limestone. In the West Indies, the $\mathrm{pH}$ of these soils ranges between 7.2 and 8.6; the phosphorus availability as defined by Ayres \& Hagihara (1961) ranged between 22 and $35 \mathrm{mg}$ $\mathrm{P} / \mathrm{kg}$ in Truog-Ayres buffer extract; and the cation exchange capacity (CEC) ranged from 500 to $800 \mathrm{mmol} / \mathrm{kg}$ (Colmet-Daage, 1982). The experiment was laid out as a split-plot (cultivars as main plot and fertilization level as sub-plot) with four blocks of six plots. Two samples were collected per plot (five plants obtained from the middle rows of plots) for each combination (total $=48$ samples). Only sugarcane cultivars B 69379 and B 744740 were used. Sugar/fiber ratio of these cultivars ranged between 0.90 and 0.98 (Salas et al., 1992). The three levels of nitrate fertilizers were 80,150 and $30 \mathrm{~kg} \mathrm{~N} / \mathrm{ha} / \mathrm{yr}$ applied in a single application eight months before sampling. Phosphorus and potassium fertilizers were $60 \mathrm{~g} \mathrm{P} / \mathrm{ha} / \mathrm{yr}$ (Superphosphate) and $180 \mathrm{~kg} \mathrm{~K} /$ $\mathrm{ha} / \mathrm{yr}$ for all plots applied $1.5 \mathrm{mo}$ after the beginning of the experiment. Husbandry operations were carried out according to sugar industry recommendations (C.T.I.C.S., 1987): weedings, treatments against parasitosis, irrigation one day per week during the first three months. Sugarcane was harvested at 12 months. Sampling procedure and separation of tops were performed as described in experiment 1 . Mineral content was determined in tops and stalks and the whole plant as described for the first experiment. 


\section{Chemical analysis}

Dry matter (DM) of samples was assessed by drying for $48 \mathrm{~h}$ at $60^{\circ} \mathrm{C}$. Samples were ground with an inox grinding sieve at $0.5 \mathrm{~mm}$ before determinations of minerals. Minerals were determined by ICP emission spectrometry with standardized procedure (ISO 6498-1983, ISO 6496-1983, ISO 6491-1980, ISO 6490.2-1983 (Theiller, 1984). Accuracies of ICP determinations were controlled with samples of the National Bureau of Standards U.S. (ref. SRM 1573, SRM 1572, SRM 1575) and European Community Bureau of Reference (CRM 061, CRM 062).

\section{Computational methods}

Data were analyzed as a factorial design with fixed main effects being stage of maturity, cultivar and stalks vs. tops in experiment 1. Cultivar factor was included in model as main plot; fertilizer treatment as sub plot in the second experiment. Analyses were carried out in the first step with part of plant (stalks vs. tops) as a source of variation. In the second step, mineral contents of the plant were analyzed. The Duncan test was used for multiple means comparisons. All statistical analyses were carried out with SAS software (SAS, 1987).

\section{RESULTS}

\section{Experiment 1}

Mineral concentrations of tops, stalk and whole plants among cultivars were not significantly different. Thus results are not shown. Ash, $\mathrm{P}, \mathrm{Ca}, \mathrm{Mg}, \mathrm{Na}, \mathrm{K}, \mathrm{Mn}$ and $\mathrm{Mo}$ contents of the tops were higher than those of the stalks at both stages of maturity (Table 1). Interaction between part of plant and stage of maturity was significant. Table 1 reports data, within stage of maturity and within part of plant. Ash and calcium and magnesium contents of tops were greater in older plants than in the younger (Table 1). Stage of maturity had little effect on the mineral content of the whole plant except on ash and potassium content, which decreased with the age of plants (Table 2). The calcium content of whole plants remained low despite the bigh calcium content of tops (Table 2).

\section{Experiment 2}

The ash, $\mathrm{P}, \mathrm{Ca}, \mathrm{Mg}, \mathrm{Na}, \mathrm{K}, \mathrm{Cu}, \mathrm{Zn}, \mathrm{Mn}$ and $\mathrm{Mo}$ contents of the tops were higher than those of the stalks ( $\mathrm{P}<0.01$; Table 3 ). In contrast, sulfur content of tops was lower than that of stalks but the mean difference 
J. Agric. Univ. P.R. vOL. 80, NO. 1-2, JANUARY/APRIL 1996

TABLE 1.-Means of ash, macro-mineral and trace element contents of sugarcane grown in acid soils (Oxisols) regions of Guadeloupe (F.W.I.) according to the part of the plant (stalks us. tops) and the stage of maturity ( 8 months us. 12 months).

\begin{tabular}{lcccccc}
\hline Item & \multicolumn{1}{c}{ stalks } & tops & stalks & $\begin{array}{c}\text { tops } \\
12 \text { months }\end{array}$ & 12 months & S.E.' \\
\hline Ash & g $/ \mathrm{kg} \mathrm{DM}$ & $27.30 \mathrm{a}^{2}$ & $61.40 \mathrm{~b}$ & $19.70 \mathrm{a}$ & $74.50 \mathrm{c}$ & 13.85 \\
$\mathrm{P}$ & $\mathrm{g} / \mathrm{kg} \mathrm{DM}$ & $1.21 \mathrm{a}$ & $1.59 \mathrm{~b}$ & $1.13 \mathrm{a}$ & $1.67 \mathrm{~b}$ & 0.39 \\
$\mathrm{Ca}$ & $\mathrm{g} / \mathrm{kg} \mathrm{DM}$ & $1.16 \mathrm{a}$ & $3.30 \mathrm{~b}$ & $0.94 \mathrm{a}$ & $4.33 \mathrm{c}$ & 1.02 \\
$\mathrm{~S}$ & $\mathrm{~g} / \mathrm{kg} \mathrm{DM}$ & $1.88 \mathrm{a}$ & $1.86 \mathrm{a}$ & $1.87 \mathrm{a}$ & $1.86 \mathrm{a}$ & 0.24 \\
$\mathrm{Mg}$ & $\mathrm{g} / \mathrm{kg} \mathrm{DM}$ & $0.78 \mathrm{a}$ & $1.21 \mathrm{~b}$ & $0.95 \mathrm{ab}$ & $1.39 \mathrm{c}$ & 0.39 \\
$\mathrm{Na}$ & $\mathrm{g} / \mathrm{kg} \mathrm{DM}$ & $0.12 \mathrm{a}$ & $0.31 \mathrm{~b}$ & $0.07 \mathrm{a}$ & $0.54 \mathrm{c}$ & 0.11 \\
$\mathrm{~K}$ & $\mathrm{~g} / \mathrm{kg} \mathrm{DM}$ & $7.96 \mathrm{ab}$ & $12.67 \mathrm{c}$ & $4.14 \mathrm{a}$ & $10.67 \mathrm{bc}$ & 3.80 \\
$\mathrm{Cu}$ & $\mathrm{mg} / \mathrm{kg} \mathrm{DM}$ & $2.38 \mathrm{a}$ & $1.84 \mathrm{a}$ & $1.64 \mathrm{a}$ & $1.80 \mathrm{a}$ & 1.44 \\
$\mathrm{Zn}$ & $\mathrm{mg} / \mathrm{kg} \mathrm{DM}$ & $16.90 \mathrm{a}$ & $20.80 \mathrm{a}$ & $16.90 \mathrm{a}$ & $18.60 \mathrm{a}$ & 6.66 \\
$\mathrm{Mn}$ & $\mathrm{mg} / \mathrm{kg} \mathrm{DM}$ & $67.60 \mathrm{a}$ & $140.40 \mathrm{~b}$ & $61.90 \mathrm{a}$ & $159.40 \mathrm{~b}$ & 52.11 \\
$\mathrm{Mo}$ & $\mathrm{mg} / \mathrm{kg} \mathrm{DM}$ & $0.34 \mathrm{a}$ & $0.68 \mathrm{~b}$ & $0.28 \mathrm{a}$ & $0.72 \mathrm{~b}$ & 0.23 \\
\hline
\end{tabular}

'SE: Standard error of mean.

${ }^{2} \mathrm{Means}$ within rows with unlike subscripts differ significantly $(\mathrm{P}<0.01)$.

was small ( $0.04 \mathrm{~g} \mathrm{~S} / \mathrm{kg} \mathrm{DM})$. Interactions between part of plant and fertilization factors, or part of plant and cultivar factors, were not significant in mineral contents at a risk lower than $1 \%$. There were few effects of the cultivar on the mineral content of each part of the plants and on whole plants (Tables 3 and 4). Nitrate fertilization slightly but significantly $(\mathrm{P}<0.01)$ increased the magnesium and copper content of each part of the plant and of whole plants (Tables 3 and 4).

\section{DISCUSSION}

Few data exist on mineral composition of sugarcane. McDowell et al. (1974) presented 10 references which reported some mineral analyses in "Latin American Table of Feed Composition"; most were only for calcium and phosphorus. Concentrations ranged from 0.7 to $12.3 \mathrm{~g} \mathrm{Ca} /$ $\mathrm{kg} \mathrm{DM}$ and from 0.9 to $6 \mathrm{~g}$ P/kg DM. Sen (1938, cited by Gohl, 1975) reported values of $3.9 \mathrm{~g} \mathrm{Ca} / \mathrm{kg} \mathrm{DM}$ and $0.6 \mathrm{~g} \mathrm{P} / \mathrm{kg} \mathrm{DM}$ in the whole plant. Another source of data is the studies on the foliar diagnosis for sugarcane, but the analysis is generally limited to the limb of the 3rd-6th leaves (Bassereau, 1984). Our results contrasted with these reports because, even in a calcarous area, calcium concentrations of the whole plant averaged $1.5 \mathrm{~g} \mathrm{Ca} / \mathrm{kg} \mathrm{DM}$. on the other hand, the phosphorus concentration that we have recorded, agreed with that reported in the literature, since we have recorded $P$ concentrations ranging from 0.6 to $1.7 \mathrm{~g}$ P/kg DM. To our knowledge, only one reference exists for calcium 
'TABLE 2.-Means of ash, macro-mineral and trace element contents of sugarcane (whole plants) grown on acid soil (Oxisols) regions of Guadeloupe (F.W.I.) according to the stage of maturity ( 8 months vs, 12 months).

\begin{tabular}{lcccc}
\hline Item & \multicolumn{1}{c}{ unit } & 8 months & 12 months & S.E.' \\
\hline Propor ${ }^{2}$ & - & $0.40 \mathrm{a}^{3}$ & $0.23 \mathrm{~b}$ & 0.07 \\
Ash & g/kg DM & $40.50 \mathrm{a}$ & $34.50 \mathrm{~b}$ & 5.48 \\
$\mathrm{P}$ & g/kg DM & $1.35 \mathrm{a}$ & $1.27 \mathrm{a}$ & 0.33 \\
$\mathrm{Ca}$ & g/kg DM & $1.99 \mathrm{a}$ & $1.86 \mathrm{a}$ & 0.55 \\
$\mathrm{~S}$ & $\mathrm{~g} / \mathrm{kg} \mathrm{DM}$ & $1.87 \mathrm{a}$ & $1.88 \mathrm{a}$ & 0.21 \\
$\mathrm{Mg}$ & $\mathrm{g} / \mathrm{kg} \mathrm{DM}$ & $0.96 \mathrm{a}$ & $1.08 \mathrm{a}$ & 0.24 \\
$\mathrm{Na}$ & $\mathrm{g} / \mathrm{kg} \mathrm{DM}$ & $0.20 \mathrm{a}$ & $0.20 \mathrm{a}$ & 0.06 \\
$\mathrm{~K}$ & $\mathrm{~g} / \mathrm{kg} \mathrm{DM}$ & $9.75 \mathrm{a}$ & $5.87 \mathrm{~b}$ & 3.08 \\
$\mathrm{Cu}$ & $\mathrm{mg} / \mathrm{kg} \mathrm{DM}$ & $2.18 \mathrm{a}$ & $1.75 \mathrm{a}$ & 1.28 \\
$\mathrm{Zn}$ & $\mathrm{mg} / \mathrm{kg} \mathrm{DM}$ & $18.50 \mathrm{a}$ & $17.20 \mathrm{a}$ & 4.67 \\
$\mathrm{Mn}$ & $\mathrm{mg} / \mathrm{kg} \mathrm{DM}$ & $96.60 \mathrm{a}$ & $89.20 \mathrm{a}$ & 38.60 \\
$\mathrm{Mo}$ & $\mathrm{mg} / \mathrm{kg} \mathrm{DM}$ & $0.49 \mathrm{a}$ & $0.40 \mathrm{a}$ & 0.16 \\
\hline
\end{tabular}

'SE: Standard error of mean.

2Propor: ratio weight of stalks ( $\mathrm{kg} \mathrm{DM}$ ) to weight of stalks and tops ( $\mathrm{kg} \mathrm{DM}$ ).

${ }^{3}$ Means within rows with unlike subscripts differ significantly $(\mathrm{P}<0.01)$.

(2.7 $\mathrm{g} / \mathrm{kg} \mathrm{DM})$, phosphorus (0.9 $\mathrm{g} / \mathrm{kg} \mathrm{DM})$, potassium (7.5 g/kg DM) and zinc $(26 \mathrm{mg} / \mathrm{kg} \mathrm{DM}$ ) of the stalks (McDowell et al., 1974). Australian tables of feed composition give $3.1 \mathrm{mg} \mathrm{Mg} / \mathrm{kg} \mathrm{DM}$ and $0.2 \mathrm{~g} \mathrm{Na} / \mathrm{kg} \mathrm{DM}$ for stalk of sugarcane. There are no data for the other minerals (i.e., S, Cu, Mo) concentrations of the different parts of sugarcane.

Despite the close resemblance to tissue separation worded "stem vs. leaf" which is commonly used for forages, "tops vs. stalk" designation was accepted through use by sugarcane scientists and for animal feeding purposes. The results of our two experiments demonstrate that stalk and tops of sugarcane differ in mineral composition. The mineral content of the tops is similar to that reported by Aumont et al. (1996) for Digitaria decumbens and other natural grasses of Guadeloupe (French West Indies). The stalks were of lower mineral content than the tops. These results agreed with other reports reviewed by Minson (1980) for tropical forages. However, in contrast to the forage (legumes or grasses) the most important part for ruminant feeding in terms of yield and nutritive values is the stalk. As compared to the effect of "part of plants," age of plant, cultivar and nitrate fertilization had little effect on the mineral content of sugarcane. These results contrasted with what was reported for mineral and trace elements in forages. As the plant matures, mineral and trace element contents decline, because of a dilution process and translocation of some minerals to the root sys- 


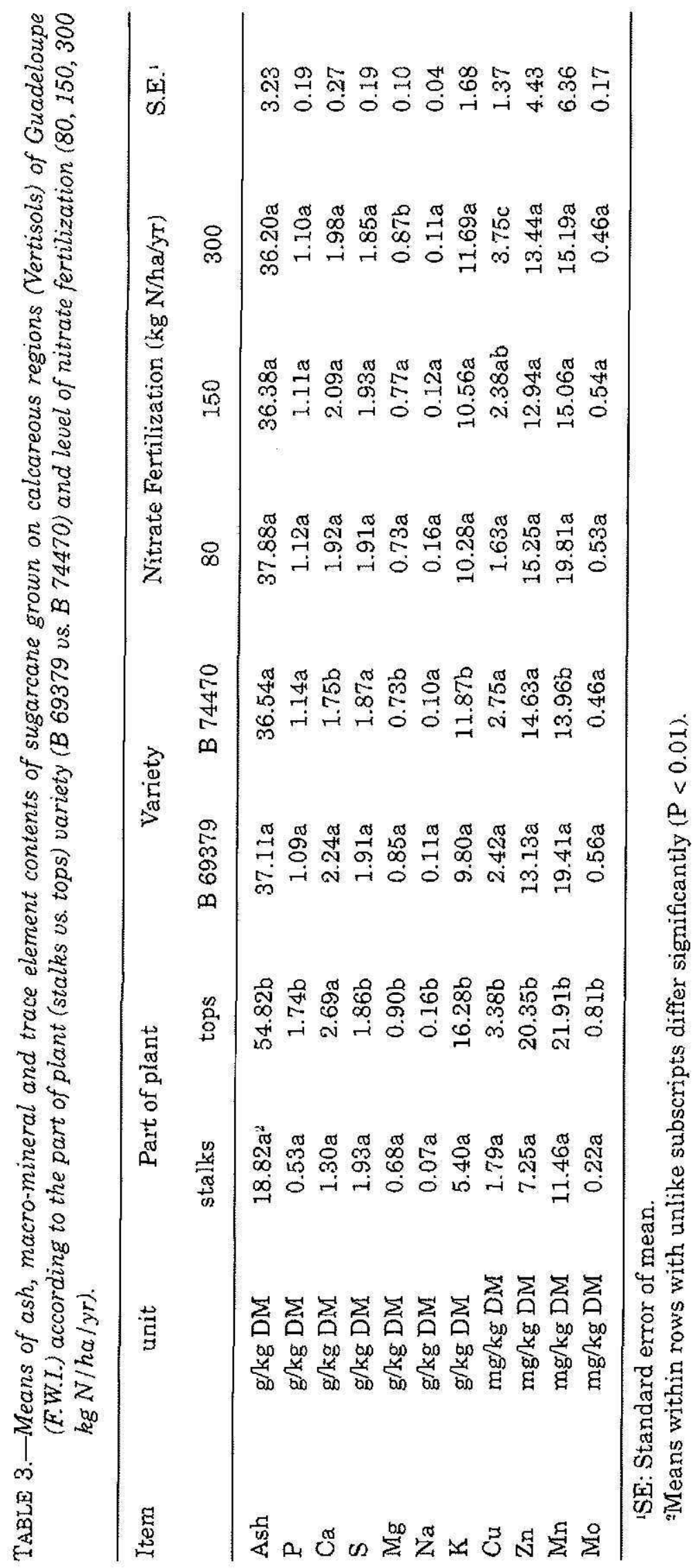


TABLE 4.-Means of ash, macro-mineral and trace element contents of sugarcane (whole plant) grown on calcareous regions (Vertisols) of Guadeloupe (F.W.I.) according to variety (B 6.937 .9 vs. B 74470) and level of nitrate fertilization $(80,150,300 \mathrm{~kg} N / \mathrm{ha} / \mathrm{yr})$.

\begin{tabular}{lcrrrrrr}
\hline Item & \multirow{2}{*}{ unit } & \multicolumn{2}{c}{ Variety } & Nitrate fertilization (kg N/ha/yr) & S.E.' \\
& & B 69379 & B 74470 & \multicolumn{1}{c}{80} & 150 & 300 & \\
\hline Propor $^{2}$ & $(\%)$ & $20.66 \mathrm{a}^{3}$ & $15.33 \mathrm{~b}$ & $19.38 \mathrm{a}$ & $18.25 \mathrm{a}$ & $16.38 \mathrm{a}$ & 3.27 \\
$\mathrm{Ash}$ & $\mathrm{g} / \mathrm{kg} \mathrm{DM}$ & $26.57 \mathrm{a}$ & $23.90 \mathrm{a}$ & $26.35 \mathrm{a}$ & $25.47 \mathrm{a}$ & $23.97 \mathrm{a}$ & 2.38 \\
$\mathrm{P}$ & $\mathrm{g} / \mathrm{kg} \mathrm{DM}$ & $0.77 \mathrm{a}$ & $0.70 \mathrm{a}$ & $0.84 \mathrm{a}$ & $0.73 \mathrm{ab}$ & $0.63 \mathrm{~b}$ & 0.13 \\
$\mathrm{Ca}$ & $\mathrm{g} / \mathrm{kg} \mathrm{DM}$ & $1.78 \mathrm{a}$ & $1.35 \mathrm{~b}$ & $1.46 \mathrm{a}$ & $1.66 \mathrm{a}$ & $1.57 \mathrm{a}$ & 0.23 \\
$\mathrm{~S}$ & $\mathrm{~g} / \mathrm{kg} \mathrm{DM}$ & $1.91 \mathrm{a}$ & $1.93 \mathrm{a}$ & $1.91 \mathrm{a}$ & $1.98 \mathrm{a}$ & $1.88 \mathrm{a}$ & 0.16 \\
$\mathrm{Mg}$ & $\mathrm{g} / \mathrm{kg} \mathrm{DM}$ & $0.79 \mathrm{a}$ & $0.65 \mathrm{~b}$ & $0.67 \mathrm{a}$ & $0.71 \mathrm{a}$ & $0.78 \mathrm{a}$ & 0.09 \\
$\mathrm{Na}$ & $\mathrm{g} / \mathrm{kg} \mathrm{DM}$ & $0.10 \mathrm{a}$ & $0.78 \mathrm{a}$ & $0.09 \mathrm{a}$ & $0.09 \mathrm{a}$ & $0.09 \mathrm{a}$ & 0.03 \\
$\mathrm{~K}$ & $\mathrm{~g} / \mathrm{kg} \mathrm{DM}$ & $7.06 \mathrm{a}$ & $7.49 \mathrm{a}$ & $7.19 \mathrm{a}$ & $7.23 \mathrm{a}$ & $7.40 \mathrm{a}$ & 0.99 \\
$\mathrm{Cu}$ & $\mathrm{mg} / \mathrm{kg} \mathrm{DM}$ & $2.30 \mathrm{a}$ & $1.78 \mathrm{a}$ & $1.29 \mathrm{a}$ & $1.78 \mathrm{ab}$ & $3.03 \mathrm{~b}$ & 0.89 \\
$\mathrm{Zn}$ & $\mathrm{mg} / \mathrm{kg} \mathrm{DM}$ & $10.00 \mathrm{a}$ & $8.78 \mathrm{a}$ & $12.15 \mathrm{a}$ & $8.46 \mathrm{~b}$ & $7.57 \mathrm{~b}$ & 2.39 \\
$\mathrm{Mn}$ & $\mathrm{mg} / \mathrm{kg} \mathrm{DM}$ & $15.23 \mathrm{a}$ & $11.75 \mathrm{a}$ & $16.70 \mathrm{a}$ & $12.31 \mathrm{a}$ & $11.45 \mathrm{a}$ & 4.02 \\
$\mathrm{Mo}$ & $\mathrm{mg} / \mathrm{kg} \mathrm{DM}$ & $0.39 \mathrm{a}$ & $0.28 \mathrm{~b}$ & $0.36 \mathrm{a}$ & $0.36 \mathrm{a}$ & $0.28 \mathrm{a}$ & 0.07 \\
\hline
\end{tabular}

'SE: Standard error of mean.

Propor: ratio weight of stalks ( $\mathrm{kg} \mathrm{DM}$ ) to weight of stalks and tops ( $\mathrm{kg} \mathrm{DM}$ ).

"Means within rows with unlike subscripts differ significantly $(P<0.01)$.

tem (Minson, 1990). In experiment 1, it appeared that between eight and $12 \mathrm{mo}$ of age, minerals of sugarcane changed to ranges that are generally below mineral requirements of ruminants (Guegen and Lamand, 1980). However, these changes were on a minor scale, as were changes for energy and nitrogen nutritive values (Salas et al., 1992). Fertilization is known to interact with other factors, such as type and $\mathrm{pH}$ of soil, on the $\mathrm{Ca}, \mathrm{Na}, \mathrm{Zn}$ and $\mathrm{Mn}$ content of forages (Gomide, 1978; Minson, 1990; Salette et al., 1973). However, in experiment 2, the mineral content of sugarcane was unchanged by nitrate fertilization.

Soil characteristics are well known to affect mineral content of the plant. Statistical analyses cannot be performed on our data to estimate the effects of soil (Oxisols vs. Vertisols) on mineral content of sugarcane without effects of year (climatic conditions) and would require adjustment to a same stage of maturity and cultivars. However, our results suggested that differences between experiments are similar to those of soil effects that were reported for Digitaria decumbens and other natural forages of Guadeloupe (Salas et al., 1992) and compilations of other authors in tropical areas (McDowell, 1985; Minson 1990). The phosphorus contents of plants grown on Oxisols were higher than of those grown on Vertisols, according to the higher phosphorus availability of this 
type of Oxisols (Colmet-Daage, 1982). The effects of soil pH on the availability of manganese for plant uptake are well documented (Minson, 1990; Underwood, 1981). Thus, soil $\mathrm{pH}$ may explain the large differences between the $\mathrm{Mn}$ content of sugarcane grown on Oxisols and that in Vertisols.

Our results can be equated to the requirements of nursing cows and bulls of medium performance because it is these types of animals which are often fed with diet composed of sugarcane. The requirements are 2 to $4 \mathrm{~g} \mathrm{Ca} / \mathrm{kg} \mathrm{DM} ; 1.8$ to $4 \mathrm{~g} \mathrm{P} / \mathrm{kg} \mathrm{DM} ; 1 \mathrm{~g} \mathrm{Mg} / \mathrm{kg} \mathrm{DM}$ (Guegen and Lamand, 1980; NRC, 1984); 1 to $2 \mathrm{~g}$ S/kg DM (Elam, 1975; Siebert, 1976); $1 \mathrm{Na} / \mathrm{kg} \mathrm{DM}$ and $6 \mathrm{~g} \mathrm{~K} / \mathrm{kg}$ DM; $30 \mathrm{mg} \mathrm{Zn} / \mathrm{kg}$ DM; $7 \mathrm{mg} \mathrm{Cu} / \mathrm{kg} \mathrm{DM} ; 30 \mathrm{mg}$ $\mathrm{Mn} / \mathrm{kg}$ DM (Guegen and Lamand, 1980; Underwood, 1981). Sugarcane contained insufficient phosphorus, calcium, magnesium, zinc and copper, irrespective of treatment applied. In calcareous areas, specific attention must be paid to phosphorus, zinc and manganese as it was found for forages from calcareous parts of Guadeloupe (Aumont et al., 1996). From our results, it can be expected that diets based on sugarcane with a degradable source of sulfur would lead to trouble in cattle

because the copper contents were frequently lowex than $4 \mathrm{mg} \mathrm{Cu} / \mathrm{kg}$ DM. Further studies on animal nutrition are required to determine the effect on health and production, of diets composed of sugarcane with such mineral and trace element content.

Tops and stalks of sugarcane present specific macro-minerals and trace elements that are affected by age of plant and nitrate fertilization. Mineral supplements including calcium, phosphorus, zinc and copper must be given to cattle fed with diets composed to a large extent of sugarcane. The part of plant used must be taken into account.

\section{LITERATURE CITED}

Aumont, G., A. Xande and J. Bellanger, 1996. Mineral and trace element content of pangola grass and other forages in Guadeloupe (F.W.I.). J. Agric. Univ. P.R. 80:2135.

Ayres, A. S. and H. H. Hagihara, 1961. Effectiveness of raw rock phosphate for sugarcane. Soil Sci., 91:383-387.

Bassereau, D., 1984. Diagnostic foliaire pour la canne a sucre. In "I'Analyse Végétale dans le Contrôle de l'Alimentation des Plantes tempérées et tropicales", p. 557-590, Martin-Prevel, P., J. Gagnard and P. Gauthier, eds., Lavoisier edition, Paris.

Colmet-Daage, F., 1982. In "Atlas de la Guadeloupe", CELET-CNRS Ed., Bordeaux.

C.T.I.C.S. (Centre Technique d'Information sur la Canne à Sucre), 1987. Le livret du panteux; Abymes (Guadeloupe, F.W.I.), 56 pp.

Elam, C. J.,1975. Sulfur requirements of ruminants. Feedstuffs 47:23-25.

Gohl, B., 1975. Tropical feeds. F.A.O. publication, Rome.

Gomide, J. A., 1978. Mineral composition of grasses and tropical leguminous forages. In "Latin American Symposium on Mineral Nutrition Research wilh Grazing Rumi- 
nants". pp. 32-40. Conrad, J. H. and L. R. McDowell, Ed. University of Florida, Gainesville, USA.

Guegen, L. and M. Lamand,1980. Mineraux. In "L'alimentation des ruminants", pp. 129142, Jarrige, R, ed., 2nd edition, INRA publications, Paris.

McDowell, L. R., 1985. Contribution of tropical forages and soil toward meeting mineral requirements of grazing ruminant. In "Nutrition of grazing ruminants in warm climates". pp. 165-188. McDowell, L. R. ed., Academic press, Inc. London.

McDowell, L. R., J. H. Conrad, J. E. Thomas and L. E. Harris, 1974. Latin american tables of feed composition. pp. 509. University of Florida, Gainesville, USA.

Minson, D. J., 1990. Forage in ruminant nutrition. pp. 461. H. B. Jovanovich ed., Academic press, San Diego.

NRC, 1984. Nutrient requirements of domestic animals. 5 . Nutrient requirements of beef cattle (6th ed.). National Academy of Sciences. National Research Council, Washington, D.C.

Preston, T. R., 1977. Nutritive value of sugarcane for ruminants. Trop. Anim. Prod., $2: 125-142$.

Salas, M., G. Aumont, G. Biessy and E. Magnie, 1992. Effect of variety, stage of maturity and nitrate fertilization on nutritive value of sugarcane. Anim. Feed. Sci. Technol., 39:265-277.

Salette, J. E., Y. Dumas and O. Sobesky, 1973. Données sur les eléments minéraux chez Digitaria decumbens cultivè dans divers milieux. Agron. Trop. 26:833-845.

SAS, 1987. 6th Edition, SAS Institute Inc., Cary, North Carolina, USA.

Siebert, B. D., R. A. Hunter and P. N. Jones, 1976. The utilization by beef cattle of sugarcane supplemented with animal protein, plant protein or non protein nitrogen and sulphur. Austr: J. Exp. Agric. Anim. Husb. 83:789-794.

Theiller, G., 1984. Résultats analytiques sur de nouveaux élalons végétaux. In "Proceedings of VIth International Colloquium for the optimization of plant nutrition". pp. 1339-1348. Martin-Prevel, P. ed., Montpellier, France.

Underwood, E. J., 1981. Mineral nutrition of livestock, second Edition, pp. 180, Commonwealth Agricultural Bureaux ed., London. 